\title{
THE ROLE OF MICRORNAS AS A DIAGNOSTIC BIOMARKERS IN THE EARLY PREDICTION OF ACETAMINOPHEN-INDUCED LIVER INJURY
}

\author{
DORA BOGHITOIU ${ }^{\# * *}$, ALINA GRAMA ${ }^{2}$, TUDOR POP $^{2}$, ANCA SIMIONESCU $^{3}$, ISABEL \\ GHITA $^{4}$, CORIOLAN EMIL ULMEANU ${ }^{\circledR}{ }^{*}$, VIORELA NITESCU ${ }^{1}{ }^{*}$ \\ ${ }^{I}$ Emergency Clinic Hospital for Children "Grigore Alexandrescu”, University of Medicine and Pharmacy "Carol Davila", \\ Bucharest, Romania \\ ${ }^{2} 2^{\text {nd }}$ Paediatric Discipline, Department of Mother and Child, University of Medicine and Pharmacy “Iuliu Hațieganu”, Cluj- \\ Napoca, Romania \\ ${ }^{3}$ Filantropia Hospital, University of Medicine and Pharmacy "Carol Davila", Bucharest, Romania \\ ${ }^{4}$ Pharmacology and Pharmacotherapy Department, University of Medicine and Pharmacy "Carol Davila", Bucharest, Romania
}

*corresponding author: doraboghitoiu@yahoo.com

${ }^{\#}$ Authors with equal contribution.

Manuscript received: December 2020

\begin{abstract}
Toxic liver injury can vary from asymptomatic increases in biochemical parameters (hepatic function tests) to acute hepatitis and acute liver failure or death. Because this parameters changes only after the hepatocellular necrosis and changes are not proportional to the extension of the hepatic injuries, we need new biological markers to facilitate an early diagnosis, allowing a rapid and targeted therapeutical intervention. Our study aimed to analyse the changes in serum levels of some miRNAs after acetaminophen exposure in mice and their correlation with the severity of liver histopathological lesions. The serum level of miRNA-122 and miRNA-192 and the histopathological aspects were assessed at 30 minutes, 2 hours, and 24 hours after intraperitoneal administration of acetaminophen. Thirty minutes post-exposure, there were no significant differences regarding the necrosis score between the acetaminophen and control groups, but the miRNA-122 values varied significantly. The level of miRNA-122 had the highest increase after 2 hours, long before any change in the serum level of the usual markers. Regarding the expression miRNA-192, at 30 minutes post-exposure, there was an increase compared to the controls, but with a magnitude inferior to that recorded for miRNA-122 (0.62 vs. 2.1). Also, after 2 and 24 hours, the increase was much less significant than for miRNA-122. With a high specificity for hepatocytes and increased stability, the serum level of miRNA-122 is modified during the early stages, even before the histopathologic changes. All of these are the necessary attributes to be a biomarker of toxic hepatic injury. miRNA-192 cannot be considered a sensitive and specific enough biomarker to toxic liver injury.
\end{abstract}

\section{Rezumat}

Boala hepatică toxică variază de la creșteri asimptomatice ale parametrilor biochimici (teste funcționale hepatice) la hepatită acută, insuficiență hepatică acută sau deces. Deoarece acești parametri se modifică numai după necroza hepatocelulară și modificările nu sunt proporționale cu extinderea leziunilor hepatice, avem nevoie de noi markeri pentru un diagnostic precoce și o intervenție terapeutică rapidă și țintită. Studiul nostru a analizat modificările nivelurilor serice ale unor microARN (miARN) după expunerea la acetaminofen la șoareci și corelația acestora cu severitatea leziunilor histopatologice hepatice. Modificările miARN-122 și 192 și aspectele histopatologice au fost evaluate la 30 de minute, 2 ore și 24 de ore după administrarea intraperitoneală de acetaminofen. La treizeci de minute după expunere, nu au existat diferențe semnificative ale scorului de necroză între lotul expus și martor, dar valorile miARN-122 au variat semnificativ. Nivelul miARN-122 a avut cea mai mare creștere după 2 ore, cu mult înainte de orice modificare a markerilor obișnuiți. În ceea ce privește miARN-192, la 30 de minute după expunere, a existat o creștere comparativ cu lotul martor, dar cu o magnitudine inferioară celei înregistrate pentru miARN-122 (0,62 față de 2,1). De asemenea, după 2 și 24 de ore, creșterea a fost mult mai puțin semnificativă decât pentru miARN-122. Cu o specificitate ridicată pentru hepatocite și stabilitate crescută, nivelul seric al miARN-122 este modificat în primele etape, chiar înainte de modificările histopatologice, putând reprezenta un biomarker al leziunilor hepatice toxice. miARN-192 nu poate fi considerat un biomarker suficient de sensibil și specific pentru leziunile hepatice toxice.

Keywords: liver injury, acetaminophen, miRNA, biomarker, laboratory parameters, mice

\section{Introduction}

Currently, toxic aetiology represent the leading cause of severe liver injuries in developing countries, responsible for $20-45 \%$ of cases that evolve with acute liver failure [1, 2]. Toxic liver injury can vary from asymptomatic increases in biochemical parameters to acute hepatitis and acute liver failure or death. The evolution depends on the ingested toxic, the dose, or each individual's 
response. In the whole world, acetaminophen is the most common cause of drug-induced acute hepatitis and an important cause of acute liver failure (ALF) $[1,3]$. Currently, clinical and laboratory parameters (encephalopathy, severe acidosis, INR, acute kidney injuries), scores (MELD, PELD, and criteria (Kings College Hospital Criteria) are used to predict the evolution of children with severe hepatotoxicity [1-4]. However, these factors can not accurately predict the unfavourable evolution. For this reason, new markers capable of quickly and accurately predicting the evolution of liver injury are needed.

There are permanent attempts to identify new biomarkers for a more rapid and accurate diagnosis of liver injury. Ozer et al. have postulated the attributes of an ideal biomarker for the diagnosis of liver injury: to have the specificity for an organ, to correlate with well-defined histopathological changes, to bring additional information to aminotransferase levels, to allow its implementation as a screening method, to be a noninvasive procedure and to keep the characteristics among species so that the clinical utilization could be possible $[5,6]$.

The study of microRNA (miRNA) could help foresee the evolution of toxic hepatic injury, these fractions being involved in the regulation of many hepatic physiological and pathological processes including hepatocyte proliferation and differentiation, apoptosis, immune responses, tissue remodelling and regeneration, by binding to and repressing complementary mRNA targets and thus protein production from the respective gene [7, 8]. Of these, miR-122, the most abundant miRNA identified in liver and with high specificity for this organ has important roles in regulating liver functions such as glucose, cholesterol and fatty-acid and iron metabolism and thereby maintaining systemic homeostasis. It has significant increase in serum concentrations in liver injury but does not denote a specific pathology or pathogenesis and the mechanisms responsible for this increase in different pathologies not well understood. In the case of acute liver damage associated with cell death miRNAs leaks from necrotic cells into the circulation. In other situations miRNA are actively secreted in relation to cell-to-cell communication [9].

MiR-192 is another miRNA that is abundant in the liver having regulatory role in cell growth, apoptosis, tumour metastasis and cell death during acute liver injury [10]. Its serum levels showed good correlations with hepatic steatosis and inflammatory activity being studied as markers for chronic hepatitis B infection, hepatic carcinoma or fatty liver disease [11].
Our study aimed to analyse the changes in serum levels of miRNA-122 and miRNA-192 after toxic doses of acetaminophen and their correlation with the severity of liver histopathological injuries by assessing all this parameters at 30 minutes, 2 hours, and 24 hours after the toxic exposure.

\section{Materials and Methods}

Experimental animals and preparation of administered substances

For each determination, we have used 24 white male mice, 25 - $35 \mathrm{~g}$ weight, delivered by the biobase of the University of Medicine and Pharmacy Carol Davila Bucharest, Romania. The animals were brought to the laboratory at least 24 hours before the beginning of the test, where standard environmental conditions were maintained. The animals had access ad libitum to food and water. They were kept in Plexiglas cages (with wood chips bed) in groups of 12 . The environmental temperature was between $21^{\circ} \mathrm{C}$ and $24^{\circ} \mathrm{C}$, and the relative moisture was $45-60 \%$. Each group of 24 mice was divided into two: 12 mice that received $400 \mathrm{mg} / \mathrm{kg}$ bw acetaminophen powder form with 99\% purity (Sigma Aldrich), corresponding to lethal dose 50, and the control group (12 mice) that received a saline solution, $0.1 \mathrm{~mL} / 10 \mathrm{~g}$ bw [13]. The acetaminophen was initially dissolved with sodium chloride $9 \%$ to obtain a concentration allowing the administration of $0.1 \mathrm{~mL} / \mathrm{g}$ volume. According to the working protocol, the lab animals treated with acetaminophen were anesthetized with diethyl ether assuring a quick installation, a short duration, and easy recovery from anaesthesia.

Blood samples collecting and measurement of serum markers.

The blood samples were collected through the puncture of the retroorbital sinus with the help of Pasteur glass pipettes, $145 \mathrm{~mm}$ long. With the tip of the pipette, we punctured the retroorbital venous plexus and collected $0.4 \mathrm{~mL}$ blood. The blood was collected in test tubes with a serum separator and, later on, centrifuged for 10 minutes at $14000 \mathrm{~g}$. The plasma resulted after centrifugation was decanted and stored at $-80^{\circ} \mathrm{C}$. MiRNA in the plasma was isolated using miRNeasy Kit (Qiagen), together with a cleaning kit, Rneasy MinElute (Qiagen), using the manufacturer's protocol. In the present study, from all the miRNA extracted, we aimed to isolate only the 122 and 192 miRNA fractions, as markers of hepatic injury. Quantitative PCR analysis was performed using the miRCURY LNA miRNA PCR kit (Qiagen) using the manufacturer's protocol. The data obtained were analysed using a soft delivered by the manufacturer: www.geneglobe.qiagen.com/analyze. 
To quantify the differences in serum level of miRNA-122 and miRNA-192 between the animals with acetaminophen exposure and controls, we used the parameter called "fold change value" (FCV) $[14,15]$. Fold change is often used in analysis of gene expression data in microarray and RNA-Seq experiments, for measuring change in the expression level of a gene. Fold change is a measure describing how much a quantity changes going from an initial to a final value [16].

Expressions of miRNA-122 and miRNA-192 were first reported as $\Delta \mathrm{Ct}$ value. The $\Delta \mathrm{Ct}$ value was estimated by subtracting $\mathrm{Ct}$ values of the endogenous control (miR-103a-3p in our experiment kit) from the $\mathrm{Ct}$ values of the target miRNA (miRNA-122 and miRNA-192). Then the $\Delta \Delta \mathrm{CT}$ was calculated by subtracting $\Delta \mathrm{CT}$ of the experimental samples with acetaminophen exposure from the control. Fold change (FC) was calculated by raising 2 to the power of the negative $\Delta \Delta \mathrm{CT}$ value [17].

Histopathology

The liver tissue samples were embedded into paraffin for four days and sectioned into $4 \mu \mathrm{m}$ thick slices, followed by staining with haematoxylin and eosin solution. The stained sections were examined under a light microscope. The assessment of histologic changes was made 30 minutes, 2 hours, and 24 hours after the toxic exposure. We evaluated the changes of the liver structure, the temporal evolution, and the correlations of the occurrence and severity of liver injuries with the miRNAs serum level. To evaluate the histopathological changes induced by hepatotoxic substances, we identified areas of hepatocellular necrosis. The severity of liver injuries was assessed as follows: 0:

without apparent injuries; $1(+)$ : congestive and necrotic injuries, limited to a small number of hepatocytes located, mainly in the centre lobular area (focal necrosis); 2 (++): congestive and necrotic injuries of hepatocytes in the centre lobular area with confluent aspect (zonal confluent necrosis); $3(+++)$ : congestive and necrotic injuries, confluent at the level of the centrilobular area, with extension towards the other zones of the hepatic lobe; $4(++++)$ : important zones of hepatocyte congestion and necrosis, with confluent aspect, located at the level of the entire hepatic lobe, with extension towards the centrilobular zones of the neighbouring lobules (confluent bridge necrosis )

We also observed other histologic changes as suggestive aspects for steatosis or inflammatory reactions.

Data Analysis and Statistics

We used descriptive statistics for continuous distribution variables (means and standard deviation, SD); the statistic relevance of comparisons was analysed using the $\mathrm{t}$-Student test. The results were considered significant at $\mathrm{p}<0.05$. Ethics statement

The research was performed according to Directive 2010/63/EU of the European Parliament and of the Council of 22 September 2010, regarding the protection of animals used for experiments or other scientific goals and under the agreement of the Board of Ethics of the University of Medicine and Pharmacy „Carol Davila” Bucharest, Romania.

\section{Results and Discussion}

The temporal evolution of FCV values for miRNA122 and miRNA-192 is presented in Table I.

Table I

The hepatic miRNA- 122 expression after the toxic exposure, presented as fold change value (FCV)

\begin{tabular}{|c|c|c|c|}
\hline & 30 minutes & 2 hours & 24 hours \\
\hline 1 & $*$ & $*$ & $*$ \\
\hline 2 & 1.8 & $*$ & $*$ \\
\hline 3 & 2.8 & 8.2 & 8.9 \\
\hline 4 & $*$ & $*$ & $*$ \\
\hline 5 & 2.1 & 8.1 & 9.1 \\
\hline 6 & 2.2 & 7.9 & 7.9 \\
\hline 7 & 2.6 & 9.1 & 9.1 \\
\hline 8 & 1.6 & 8 & 9.9 \\
\hline 9 & 2 & 8.4 & $*$ \\
\hline 10 & 2.1 & 7.6 & 10.4 \\
\hline 11 & $*$ & $*$ & $*$ \\
\hline 12 & 1.7 & 9.4 & 7.3 \\
\hline Mean \pm SD $2.100 \pm 0.37428 .3375 \pm 0.5743$ & $8.9428 \pm 0.9912$ \\
\hline p-value & $<0.0001$ & $<0.0001$ & $<0.0001$ \\
\hline
\end{tabular}

By analysing the mean values of FCV (Table II), we concluded that the expression of miRNA-122 is higher for those receiving acetaminophen compared to the controls, as early as the first 30 minutes since the toxic exposure and continued to increase at a very rapid pace for the next 2 hours: 8.33 after 2 hours comparatively to 2.10 after 30 minutes). However, during the next 24 hours, the level 
FARMACIA, 2021, Vol. 69, 4

increased more slowly and was stabilized, the mean $\quad$ value of FCV being 8.94.

Table II

The hepatic miRNA-192 expression after the toxic exposure, presented as fold change value (FCV)

\begin{tabular}{|c|c|c|c|}
\hline & 30 minutes & 2 hours & 24 hours \\
\hline 1 & $*$ & $*$ & $*$ \\
\hline 2 & 0.7 & $*$ & $*$ \\
\hline 3 & 0.8 & 6 & 6.1 \\
\hline 4 & 0.4 & $*$ & $*$ \\
\hline 5 & 0.5 & 5.8 & 5.6 \\
\hline 6 & 0.7 & 7 & 7.2 \\
\hline 7 & 0.9 & 6.3 & 6.3 \\
\hline 8 & 1 & 6.1 & 6.9 \\
\hline 9 & 0.5 & 6.4 & $*$ \\
\hline 10 & 0.4 & 8.2 & 8.2 \\
\hline 11 & $*$ & $*$ & $*$ \\
\hline 12 & 0.3 & 6.9 & 6.8 \\
\hline Mean \pm SD & $0.6200 \pm 0.22276 .5875 \pm 0.7235$ & $6.7285 \pm 0.7814$ \\
\hline p-value & $<0.0001$ & $<0.0001$ & $<0.0001$ \\
\hline
\end{tabular}

Regarding the expression miRNA-192, at 30 minutes post-exposure, there was an increase compared to the controls, but with a magnitude inferior to that recorded for miRNA-122 (0.62 vs. 2.1). Also, after 2 and 24 hours, the increase was much less significant than for miRNA-122
The evolution of FCV mean values for miRNA-122 and miRNA-192 during the experiment is illustrated in Figure 1. Next, we aimed to identify the lesions that appeared at the level of the liver structure after the administration of acetaminophen, their evaluation, based on the necrosis score, and the evolution in time (Table III).

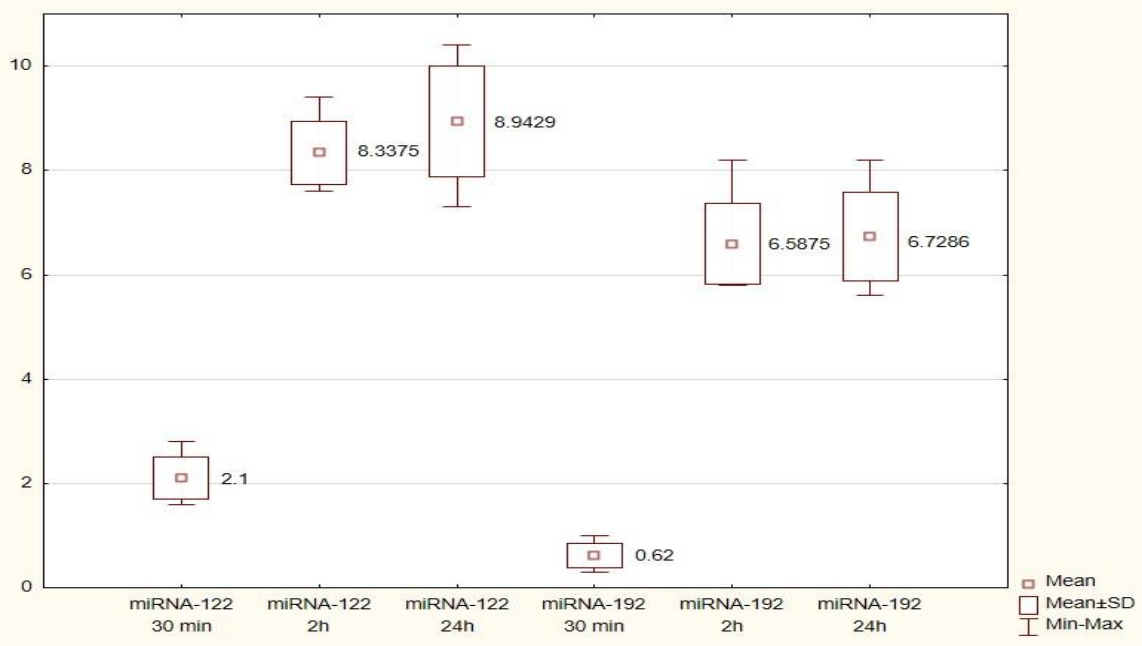

Figure 1.

Mean FCV for miRNA-122 and miRNA-192

Table III

Temporal evolution of the necrosis score after acetaminophen exposure

\begin{tabular}{|c|c|c|c|c|c|c|}
\hline \multirow{2}{*}{ Necrosis score } & \multicolumn{3}{|c|}{ Number of lab animals } & \multicolumn{3}{c|}{24 hours } \\
\cline { 2 - 7 } & \multicolumn{2}{|c|}{30 mins } & \multicolumn{2}{c|}{ 2 hours } & Control \\
\hline & Acetaminophen & Control & Acetaminophen & Control & Acetaminophen & 9 \\
\hline Score 0 & 7 & 9 & 0 & 9 & 0 & 2 \\
\hline Score 1 & 5 & 3 & 4 & 3 & 2 & 0 \\
\hline Score 2 & 0 & 0 & 4 & 0 & 4 & 0 \\
\hline Score 3 & 0 & 0 & 1 & 0 & 0 & 0 \\
\hline Score 4 & 0 & 0 & 0 & 0 & $0.25 \pm 0.43$ \\
\hline Mean \pm SD & $0.41 \pm 0.49$ & $0.25 \pm 0.43$ & $1.66 \pm 0.66$ & $0.25 \pm 0.43$ & $2.25 \pm 0.82$ & 0.25 \\
\hline
\end{tabular}

Regarding the changes in the hepatic structure, 30 minutes after the toxic exposure, most laboratory animals $(\mathrm{n}=7,58.33 \%)$ did not associate histologic changes. Five mice presented congestive and 
necrotic injuries limited to a small number of hepatocytes, evaluated as reduced severity, score 1 according to the working protocol. By analysing the mean value of this scoring in the animals exposed to paracetamol, we concluded that it is not statistically significantly higher compared to that obtained for the control group $(0.41$ for those injected with acetaminophen compared to 0.25 for controls, $\mathrm{p}=0.33$ ).

The evaluation of hepatic structure 2 hours after the intraperitoneal administration of acetaminophen pointed out that toxic hepatic injuries evolved, being present in every lab animal from the lot exposed with different levels of severity. At this stage the average value of the necrosis score differs significantly from that recorded in the case of the control group $(\mathrm{p}=0.0004)$
We analysed then when the miARNs started to increase after the toxic exposure and the hepatic histopathological changes appeared. We concluded that 30 minutes after the exposure to toxic, the necrosis score in those receiving acetaminophen was similar to the controls. At the same time, the miRNA-122 values recorded a duplication compared to the control $(\mathrm{FCV}=2.1)$.

Two hours after the toxic exposure the values of microRNA-122 recorded the most significant increase (2.10 versus 8.33$)$ while histological changes, although present in most animals, have a low degree of severity.

Temporal evolution of hepatic necrosis score and serum levels of miARN is presented in Table IV.

\begin{tabular}{|c|c|c|c|}
\hline & $30 \mathrm{mins}$ & $2 \mathrm{~h}$ & $24 \mathrm{~h}$ \\
\hline Necrosis Score (mean \pm SD) & $0.41 \pm 0.49$ & $1.66 \pm 0.66$ & $2.25 \pm 0.82$ \\
\hline miRNA-122 (FCV) & $2.10 \pm 0.37$ & $8.33 \pm 0.57$ & $8.94 \pm 0.99$ \\
\hline miRNA-192 (FCV) & $0.62 \pm 0.22$ & $6.59 \pm 0.72$ & $6.73 \pm 0.78$ \\
\hline
\end{tabular}

Because miRNA 122 registered significant variations, we verified, by means of the Pearson correlation coefficient ( $r$ ), if this changes are statistically significantly correlated with the histopathological changes, respectively the liver necrosis score. In the case of MiRNA 122, 30 minutes after toxic exposure there is no statistically significant correlation between the necrosis score and the increases compared to the control group ( $\mathrm{r}$ $=-0.188, \mathrm{p}=0.62)$, most of the animals having minimal histopathological changes or absent. At 2 hours post-exposure, the increases in miRNA 122 are positively correlated with histopathological changes $(r=0.5668)$ but the correlation is not statistically significant $(\mathrm{p}=0.142$ ). At 24 hours post-exposure the correlation coefficient also has negative values, indicating a inverse correlation between the evolution of necrosis score and miRNA values.

ALF is the final stage in the evolution of a liver injury, its development often rapid and severe, thus causing a significant number of deaths. To date, various markers or scores have been used to foresee the negative evolution of toxic ALF [18]. For example, prothrombin time, INR, coagulation factors V or VII, hepatic encephalopathy, liver sizes, MELD, PELD scores, or King's College criteria have been used to assess the need for a liver transplant in ALF patients [1].

Acetaminophen is safe when is used in therapeutic doses and becomes hepatotoxic in case of overdose $(>200 \mathrm{mg} / \mathrm{kg})$. However, an overdose of acetaminophen produces direct hepatotoxicity and hepatocellular necrosis. To diagnose liver injury after an acetaminophen overdose, we use a series of biochemical parameters (hepatic function tests). As these parameters change only after the hepatocellular injuries, and their changes are not proportional to the extension of the hepatic injuries, we need new biological markers to facilitate an early diagnosis, allowing a rapid and targeted therapeutical intervention.

In our study, we analysed the function of miRNAs in the context of toxic liver disease. Since the body's processes depend on the expression of a specific gene, identifying factors involved in the transcription and translation of genetic information of nuclear DNA at the synthesis of different protein structures would be very useful. The extracellular localization and the specific changes when pathologic processes appear at an organ support the idea that the dosage of miRNA can be used as a marker for a non-invasive diagnosis. Synthesis alteration of different proteins coded by the messenger RNA targeted by the miRNA particles has significant implications during cell differentiation, proliferation, or apoptosis [14-24]. MicroRNAs are expressed in various cell types of the liver. It is already well known that miRNA level is altered in almost all acute and chronic liver diseases: viral hepatitis, steatosis, cirrhosis, or hepatocellular carcinoma. Some can be detected in circulation, as they are very stable in different fluids: blood, urine, cerebrospinal fluid, as exosomes, or bound to proteins or lipoproteins [24]. Many types of miRNA were identified at the hepatic level: miRNA-21, miRNA-25, miRNA-122, 
miRNA-125b, miRNA-183, miRNA-192, miRNA155, miRNA-223.

Some types of miRNAs are involved in the regulation of hepatic development during embryogenesis or physiological or pathological processes; miRNA-122 and miRNA-192 have the highest specificity $[12,14,15]$. Moreover, in toxic liver injury, the levels of some miRNA fractions are more increased than in viral infections or hepatocellular carcinoma [25]. Thus, identifying miRNA profile allows the differentiation between the toxic aetiology and the ischemic one [26-29].

The miRNA-122 represents almost $70 \%$ of the miRNA particles [18], both in men and mice [21]. This particle interferes in regulating critical physiologic processes: hepatic circadian rhythm, lipids metabolism (fatty acids oxidation, cholesterol synthesis), hepatocytes differentiation, proliferation, or apoptosis, with increased specificity for the liver [22].

It is already known that regardless of its infectious, malignant, or toxic nature, a liver injury can determine changes of miRNA-122 levels both inside the liver structure and in circulation [22-26]. MiR-122 is abundant in hepatocytes, and recent studies have demonstrated that it may serve as a biomarker to differentiate between hepatocyte injury and inflammation, thus correlating with the etiology of liver damage [22].

In our study, at 30 minutes post-exposure, we did not detect significant differences regarding the necrosis score between the acetaminophen and control groups, but the miRNA-122 varied significantly. Also, the level of miRNA-122 had the highest increase after 2 hours, long before any change in the serum level of the usual markers of the hepatic injury. Thus, for example, ALT may take more than $72 \mathrm{~h}$ to reach peak activity in blood, and elevated ALT activity is not specific for liver injury [23-29].

These results are similar to other studies in rodents and humans with toxic liver injuries, concluding that elevations in serum miR-122 preceded significant rises in ALT activity. Circulating miRNA-122 levels can be detected in circulation before marked cell death had occurred in the liver [12,23-29], fact also supported by the negative correlation coefficient between the liver necrosis score and the increase of 122 miRNA at 30 minutes post-exposure. This finding can be explained by the fact that oxidative stress, regardless of the determining cause, would promote the release of exosome in hepatic cells in the absence of hepatocyte necrosis [30]. Level of miRNA-122 can be considered an early indicator of hepatic injury because its levels increase before apparent histopathologic injuries.
MiRNA-192 is another fraction of RNA widely studied in different diseases: asthma, lung, pancreas, and ovarian cancer. Present also in the liver, its expression can change in hepatic injury. In our study, the levels of miRNA-192 increase as early as 30 minutes after toxic exposure, but these increases were lower than those of miRNA-122. Thus, as the specificity for hepatocyte is reduced, and the toxic hepatic injury does not determine a significant increase in its level, we concluded that miRNA-192 has a lesser role in the early detection of hepatic injury than miRNA-122, although there were studies that showed a high concentration of this fraction in the liver and increased specificity for toxic liver injury [23-29].

\section{Conclusions}

MiRNA-122 has an essential and well-known role in liver physiology, and its level in different extracellular fluids changes during toxic liver injury. With a high specificity for hepatocytes and increased stability, the serum level of miRNA-122 is modified during the early stages, even before the histopathologic changes. All of these are the necessary attributes to be a biomarker of toxic hepatic injury. Regarding the miRNA-192 serum level after hepatotoxic exposure, the increase is lower than miRNA-122. The specificity for the hepatocyte is also reduced compared to miRNA122. miRNA-192 cannot be considered a sensitive and specific enough biomarker to toxic liver injury.

\section{Conflict of interest}

The authors declare no conflict of interest.

\section{References}

1. Whittington PF, Alonso WA, Fulminant hepatitis and acute liver failure. In: Deirdre K (editors): Diseases of the Liver and Biliary System in Children, $3^{\text {rd }}$ edition, Oxford, Wiley-Blackwell, 2008: 92-123

2. Burdina MK, Valkova I, Andonova L, Georgieva M, TzankovaV, Zlatkov A, Quantitative structure hepatotoxicity assessment of series arylpiperazine $\mathrm{N}$-substituted theobromine derivatives. Farmacia, 2020; 68(1): 56-64.

3. Murray KF, Hadzic N, Wirth S, Bassett M, Kelly $\mathrm{D}$, Drug-related hepatotoxicity, and acute liver failure. J Pediatr Gastroenterol Nutr., 2008; 47(4): 395-405

4. Gilbert PJ, Moreno BJ, Rodríguez SM, Aetiology, outcomes, and prognostic indicators of paediatric acute liver failure. Anales de Pediatria, 2018; 88(2): 61-112

5. Thapa BR, Walia A, Liver Function Tests and their Interpretation. Indian J Pediatrics, 2007; 74(7): 663-671 
FARMACIA, 2021, Vol. 69, 4

6. Ozer J, Ratner M, Shaw M, Bailey W, Schomaker $\mathrm{S}$, The current state of serum biomarkers of hepatotoxicity. Toxicol., 2008; 245: 194-205

7. Arrese M, Eguchi A, Feldstein A, Circulating microRNA: Emerging Biomarkers of Liver Disease. Semin Liver Dis., 2015; 35: 43-53

8. Bartel DP, MicroRNAs: genomics, biogenesis, mechanism, and function. Cell, 2004; 116(2): 281297.

9. Turchinovich A, Weiz L, Burwinkel B, Extracellular miRNAs: the mystery of their origin and function. Trends Biochem Sci., 2012; 37(11):460-465.

10. Roy S, Benz F, Alder J, Bantel H, Janssen J, Vucur M, Gautheron J, Schneider A, Schüller F, Loosen S, Luedde M, Koch A, Tacke F, Luedde T, Trautwein C, Roderburg C, Down-regulation of miR-192-5p protects from oxidative stress-induced acute liver injury. Clin Sci., 2016; 130(14): 11971207.

11. Ren FJ, Yao Y, Cai XY, Fang GY, Emerging Role of MiR-192-5p in Human Diseases. Front Pharmacol., 2021; 12: 614068: 1-15.

12. Starkey Lewis PJ, Dear J, Platt V, Simpson KJ, Craig GND, Antoine DJ, French NS, Dhaun N, Webb DJ, Costello EM, Neoptolemos JP, Moggs J, Goldring CE, Park KB, Circulating MicroRNAs as Potential Markers of Human Drug-Induced Liver Injury. Hepatol., 2011; 54(5): 1767- 1776.

13. Fraschini F, Demartini FG, Esposti D, Pharmacology of Silymarin. Clin Drug Invest., 2002; 22(1): 51-65.

14. Zhang Y, Jia Y, Zheng R, Guo Y, Wang Y, Guo H, Fei M, Sun S, Plasma MicroRNA-122 as a Biomarker for Viral-, Alcohol-, and ChemicalRelated Hepatic Diseases. Clin Chem., 2010; 56(12): 1830-1838

15. Qureshi R, Sacan A, A novel method for the normalization of microRNA RT-PCR data. BMC Medical Genomics., 2013; 6(1): S14: 1-13.

16. Zhang J, Li H, Dong J, Zhang N, Liu Y, Luo X, Chen J, Wang J, Wang A, Omics-Based Identification of Shared and Gender Disparity Routes in Hras 12 V-Induced Hepatocarcinogenesis: An Important Role for Dlk1-Dio3 Genomic Imprinting Region. Front Genet., 2021; 12: 620594: 1-15.

17. Schmittgen TD, Livak KJ, Analyzing real-time PCR data by the comparative C(T) method. Nat Protoc., 2008; 3(6): 1101-1118

18. Dragostin OM, Dragostin I, Zamfir AS, Confederat L, Stan DC, Dragan M, Tuchilus C, Zamfir CL, New isoniazid derivatives for antimicrobial spectrum extension and hepatotoxicity reduction of parent compound: in vitro and in vivo assays. Farmacia, 2020; 68(3): 532-540.
19. Ye D, Zhang T, Lou G, Liu Y, Role of miR-223 in the pathophysiology of liver diseases. Exp Mol Med., 2018; 50(9): 1-12

20. Jopling C, Liver specific microRNA-122. Biogenesis and function. RNA Biology, 2012: 9(2): 1-6

21. Lin X, Ewing LE, Koturbash I, Gurley BJ, Miousse IR, MicroRNAs as biomarkers for liver injury: current knowledge, challenges, and prospects. Food Chem Toxicol., 2017; 110: 229-239

22. Bala S, Petrasek J, Mundkur S, Catalano D, Levin I, Ward J, Alao H, Kodys K, Szabo G, Circulating microRNAs in exosomes indicate hepatocyte injury and inflammation in alcoholic, drug-induced, and inflammatory liver diseases. Hepatology, 2012; 56(5): 1946-1957.

23. Green TJ, Sivilotti ML, Langmann C, Yarema M, Juurlink D, Burns MJ, Johnson DW, When do the aminotransferases rise after acute acetaminophen overdose? Clin Toxicol., 2010; 48(8): 787-792

24. Arroyo JD, Chevillet JR, Kroh EM, Argonaute 2 complexes carry a population of circulting microRNAs independent of vesicles in human plasma. Proc Natl Accad Sci USA, 2011; 108: 5003-5008.

25. Bandiera S, Pfeffer S, Baumert TF, Zeisel M, miR122-A key factor and therapeutic target in liver disease. J Hepatol., 2015; 62: 448-457.

26. Wang $\mathrm{K}$, Zhang $\mathrm{S}$, Marzolf $\mathrm{B}$, Troisch $\mathrm{P}$, Brightman A, Hu Z, Hood LE, Galas DJ, Circulating microRNAs, potential biomarkers for drug-induced liver injury. Proc Natl Accad Sci USA, 2009; 16(11): 4402-4407.

27. Sarasin Filipowicz M, Krol J, Markiewicz I, Heim $\mathrm{MH}$, Filipowics W, Decreased levels of micoRNA miR-122 in individuals with hepatitis $\mathrm{C}$ responding poorly to interferon therapy. Nat Med., 2009; 15(1): 31-33.

28. Ding $X$, Ding J, Ning J, Yi F, Chen J, Zhao D, Zheng J, Liang $\mathrm{Z}, \mathrm{Hu} \mathrm{Z}, \mathrm{Du} \mathrm{Q}$, Circulating microRNA-122 as a potential biomarker for liver injury. Mol Med Rep., 2012; 5(6): 1428-1432.

29. Ward J, Kanchagar C, Veksler-Lublinsky I, Lee RC, McGill MR, Jaeschke H, Curry SC, Ambros VR, Circulating microRNA profiles in human patients with acetaminophen hepatotoxicity or ischemic hepatitis. Proc Natl Accad Sci USA, 2014; 111(33): 12169-12174.

30. Mosedale M, Eaddy JS, Trask OJ Jr, Holman NS, Wolf KK, LeCluyse E, Ware BR, Khetani SR, Lu J, Brock WJ, Roth SE, Watkins PB, miR-122 release in exosomes precedes overt tolvaptaninduced necrosis in a primary human hepatocyte micropatterned coculture model. Toxicol Sci., 2018; 161: 149-158. 